\title{
Historical Costs or Fair Value in Accounting: Impact on Selected Financial Ratios
}

\author{
Jiř́ Strouhal, Member, IEDRC
}

\begin{abstract}
Paper discusses the issues of currently used valuation models in financial reporting systems. During last three decades there could be seen a visible trend of shifting from traditional historical costs accounting towards fair value accounting (or mark-to-market accounting respectively). The analytical part of this paper addresses the impact of studied valuation models on selected financial ratios with the purpose of identifying the most and the less sensitive ones on various valuation models.
\end{abstract}

Index Terms-Financial reporting, revaluation models, financial analysis, IFRS, accounting harmonization.

\section{INTRODUCTION}

Dominant factor affecting a system of accounting regulation is legal system. Continental Europe is still rather based on Rome Civil Law, i.e. there could be seen a direct regulation of accounting throughout acts, decrees and various accounting standards. For this direct regulation is obvious a linkage between accounting and taxes [1]-[6]. Financial accounting is in such a case unified and cannot bring some additional effects for specific financial statement users.

Anglo-Saxon approach is oriented on common law. Regulation is principle based and the requirements are formulated obviously by professional institution in the form of accounting standards. In such a case state does not play such crucial role like under direct system of accounting regulation. This approach is intensive for the training and education of professional accountants and expects a constructive approach to accounting practices [7], [8].

Among most discussed areas between researchers and practitioners could be stated measurement of balance sheet items. Application of various measurement bases leads to very important discrepancies and inconsistencies in presented information.

Accounting theory and practice has developed quite a wide range of possible approaches to the measurement in accounting. In the interest of reliability, clarity, and comparability of accounting data are approaches to measurement in accounting a significant part of the regulation of accounting both at the national level and within international accounting harmonization. Whether it is to standardize the output of accounting, which is characteristic for Anglo-Saxon area, or whether it is to standardize current accounting practices and the related regulation of financial reporting used in continental Europe, there are always specific rules set, adjusting the measurement used for

Manuscript received November 19, 2013; revised January 14, 2014.

J. Strouhal is with the Skoda Auto University Mladá Boleslav, Czech Republic (e-mail: ystrouhal@is.savs.cz). accounting of transactions during the reporting period as well as the measurement for the preparation of financial statements [9].

Accounting rules theoretically can be based on the choice of setting a single measurement basis, which would be universally used in measurements in all situations, or may use mixed measurement approaches [10].

For local accounting practices as well as for International Financial Reporting Standards (IFRS) is characteristic the use of mixed measurement approaches. In recent years, there is an apparent effort of the International Accounting Standard Board (IASB) to establish a single measurement approach. According to Dean [11] there is growing concern that the current mixed measurement model, which combines fair value and cost within financial statements, is not the most preferred or perhaps reliable basis of accounting. Finding an appropriate solution is proving difficult.

\section{Measurement APPROACHeS}

Only one starting point can be provided for the purpose of measurement that (according to the standard setters) best satisfies the criteria of the financial accounting and reporting measurement. These measurement bases are "pure" base of measurement as historical cost, replacement cost, value in use or fair value.

The objective would always be to estimate the selected measurement basis, other bases being allowed only as proxies where direct measurement was impossible [12].

The consistency of the measurement, comparability and meaningful aggregation of the accounting data are the advantages of this approach. The adoption of single measurement method is predicated on the belief that such a measurement will be always the most relevant and will be reliably measurable. Such a "perfect" measurement basis has not yet been found. Macve [13] believes that it is impossible to prove that any individual measurement approach is Pareto superior to others for external users - ideally they probably need a range of alternative measures in order to triangulate the information they receive from various sources.

IASB attempts to find and defend such a base in its projects dealing with measurements [14]. According to the IASB's projects the fair value measurement should be such a base, however, in our opinion in many cases not even fair value meets the criteria, which a measurement in financial accounting should meet.

As stated above, virtually all systems of accounting regulation (without exception of IFRS) do not currently use a single measurement approach, required and preferred in all cases, but the mix of measurement approaches. The advantage of this approach is that it is not necessary to use a 
single measurement approach for all situations, which, considering the information needs of users, but also for example the reliability of establishing such measurement might not be appropriate in a particular situation.

"Different Measures for Different Purposes" is appropriate for financial accounting [15]-[17]. Cost measures may provide useful margins on turnover for predicting operating cash flows in a going concern business, whereas fair value may be a more direct and reliable means of valuing a portfolio of marketable investments.

However, disadvantages of using mix measurement approaches are obvious - it leads to aggregation of the data measured by different approaches, the explanatory power of such aggregation is weak, plus the use of different measurement approaches entails various risks. To report the items which are measured by different measurement approaches separately is therefore a minimum requirement, which should be held. Separate reporting of items bound to various estimating risks enables the users of financial information their independent analysis and assessment.

Measurement approaches are in practice differentiated according to both the moment at which the measurement is performed (e.g. initial recognition of the particular item or subsequent measurement) and according to nature of the subject of the measurement (e.g. long-term assets in terms of meeting the prerequisites of going concern, inventories and derivatives or securities held for trading are measured differently.)

By accepting this approach the measurement problem has been limited to the search of an appropriate measurement base for the measurement of particular items in a particular situation. Only one method of measurement would be associated with a particular item, different item would, or could, be measured using different methods, if those methods best represented the economic properties of the particular item [12].

The criteria for the choice of the measurement approach are determined by standard setters. The starting point should always be the information needs of the users of financial information. However, there are different groups of the accounting information users that have different interests and different needs. The final selection of the criteria is always dependent on the decision of the standard setters, who may and in fact must give priority to the interests of certain groups of the accounting information users [17].

If the accounting regulator is the state - a state institution (what is common in continental Europe) and if there is a close relation between accounting and taxation in the country given, the criteria for the selection of the measurement approach may be strongly influenced by the fiscal interests of the state (accounting is then subordinate to the tax aspects) and other needs of the state administration (a crucial source of demand for accounting information is the state), and the interests of other users of accounting information may not be adequately taken into account. This method of accounting regulation is often characterized by the usually not explicitly formulated basic objectives of financial reporting or conceptual framework.

Continental Europe is also characterized by the strong influence of the prudence principle in choosing the appropriate measurement approach (approaches). It was this principle together with the possibility to partly ignore the interests of the users of accounting information (investors, etc.) which is given by the fact that accounting rules are set by a government organization, which significantly influenced the criteria for selecting measurement bases and blocked or hindered the penetration of the measurement in fair value (see below) to accounting (as an example we can mention accounting in Germany or France, but also in the countries that are the subject of research in this publication).

Another situation arises in case that setting the accounting rules is carried out by a professional organization (typical of the Anglo-Saxon area). This organization starts from the interests of different groups of users (who in fact create a demand for accounting information) and tries to meet them appropriately when creating accounting policies (including the definitions of measurement approaches). The standard setters are, however even in this case before the difficult task of deciding which needs and interests of users of accounting information it is necessary to prefer and how they are optimally met.

The representative of the regulation (harmonization) of accounting, which is not subordinate to the state power, is e.g. IASB (as well as the Financial Accounting Standards Board FASB, UK Accounting Standards Board - ASB etc.) The conceptual framework of the IFRS, based on the fact that the financial statements are intended primarily to external users, analyzes the information needs of different groups and states: While not all of the information needs of users can be met by financial statements, there are needs that are common to all users. As investors are providers of risk capital to the entity, the provision of financial statements that meet their needs will also meet most of the needs of other users that financial statements can satisfy [18].

The measurement must be also subordinate to these goals. In summary, the primary criteria for evaluating possible measurement bases, derived from the conceptual frameworks, are:

1) Decision usefulness

2) Qualitative characteristics of useful information

- Understandability

- Relevance - predictive value, feedback value, timeliness

- Reliability — representational faithfulness, neutrality, verifiability

- Comparability

3) Concepts of assets and liabilities

- How the expected cash-equivalent flow attribute of assets and liabilities is measured

4) Cost/benefit considerations

\section{APPLICATION PART}

Within this application part we would try to analyze the implication of various measurement models (historical cost model, fair value model and revaluation model) used for revaluation on selected financial ratios, concretely:

1) profitability ratios: ROA, ROE, ROS

2) liquidity ratios: current ratio

3) assets turnover ratios: assets turnover

4) debt ratios: debt ratio, Equity/Debts ratio, average 
leverage, interest coverage, Assets/Debts ratio

5) capital markets ratio: EPS

For the analysis we will use these primary data Table I:

TABLE I: BALANCE SHEET OF ABC, JSC (PRIOR REVALUATION)

\begin{tabular}{|l|l|l|c|}
\hline \multicolumn{3}{|c|}{ Balance Sheet of ABC, JSC (prior revaluation) } \\
\hline $\begin{array}{l}\text { Assets subject } \\
\text { to revaluation }\end{array}$ & 1000000 & Registered capital & 2000000 \\
\hline Others assets & 9000000 & Revaluation surplus & 0 \\
\hline & & P/L & 1000000 \\
\hline & & Other parts of equity & 2000000 \\
\hline & & Income tax liabilities & 250000 \\
\hline Total assets & 10000000 & $\begin{array}{l}\text { Tother liabilities equity and } \\
\text { liabilities }\end{array}$ & 4750000 \\
\hline
\end{tabular}

Other information: revenues from sales were 20mil. CU, interest paid $200000 \mathrm{CU}$ and registered capital represents 20000 ordinary shares. Let's operate in country with income tax of $20 \%$.

We will analyze the impact of revaluation (upwards and downwards) for up to $10 \%$ on results of selected financial ratios (as stated above).

\section{A. Historical Costs Model}

Probably the most popular model in continental Europe is historical costs model. When applying this model, we have to fulfill the prudence principle perceptions and that's why we are unable to revaluate assets on higher values. When revaluating on lower values there is applied the computation of impairment.

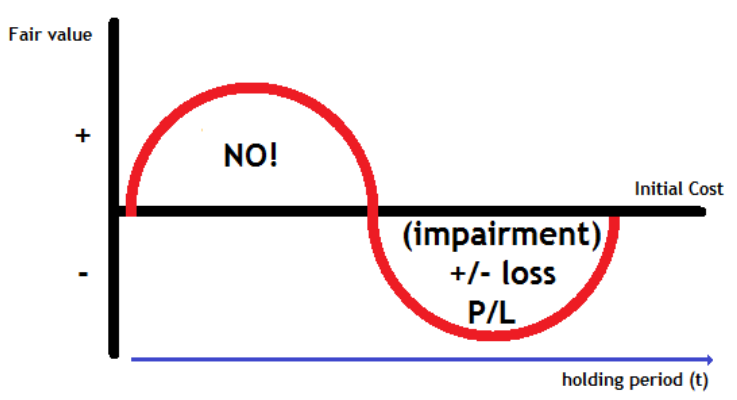

Fig. 1. Historical cost model.

Following Fig. 2 provides us information about the effect of using historical cost model on profitability ratios, liquidity ratios and assets turnover ratio:

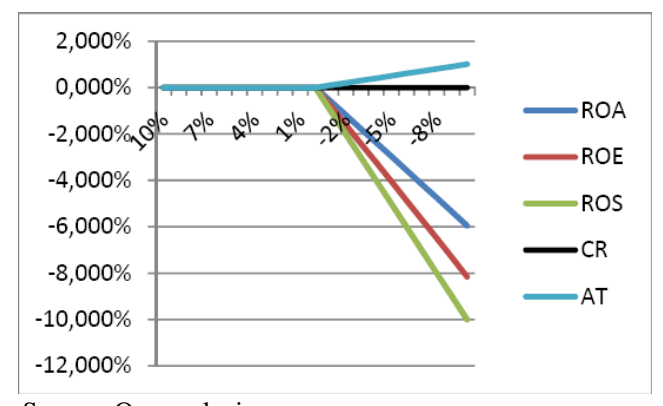

Source: Our analysis

Fig. 2. Historical costs model and financial ratios I.

When applying historical costs model linearly behaves profitability and liquidity ratios. The inverse trend could be seen (however marginal) for assets turnover ratio.
Following Fig. 3 provides us information about the effect of using historical cost model on debt ratios and earnings per share:

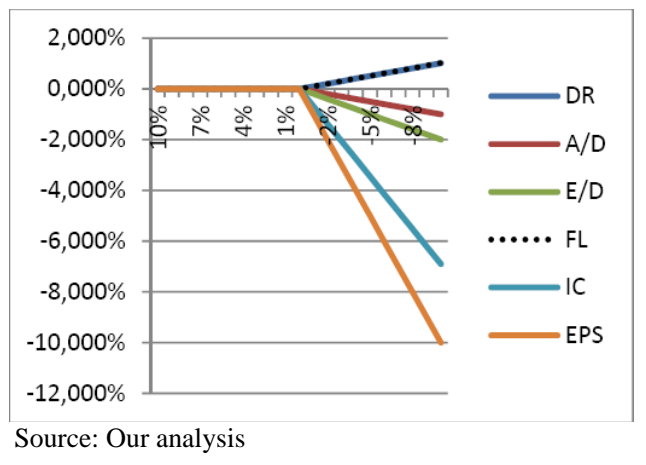

Fig. 3. Historical costs model and financial ratios II.

When applying historical costs model, proportional trend is visible within EPS analysis. All other ratios (with the exemption of debt ratio and financial leverage) show identical trend, but less proportional. The inverse trend of debt ratio and financial leverage could be explained by the fact that higher the value of these ratios, higher the debt exposure of the company.

\section{B. Fair Value Model}

Second model being a subject of our analysis would be fair value model, which is currently used mainly for revaluation of selected financial instruments, investment properties and biological assets.

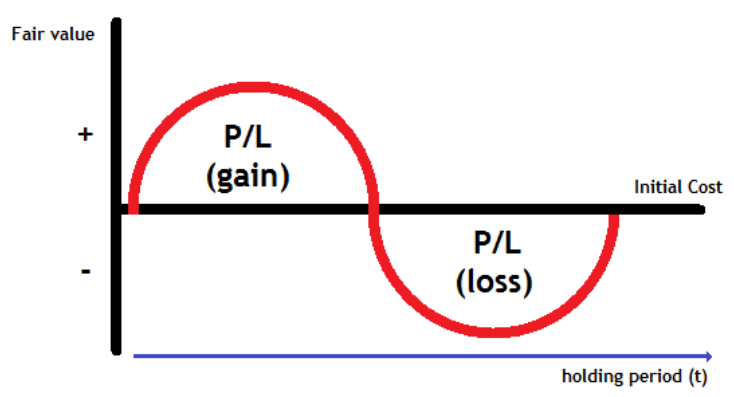

Fig. 4. Fair value model.

Following Fig. 5 provides us information about the effect of using fair value model on profitability ratios, liquidity ratios and assets turnover ratio:

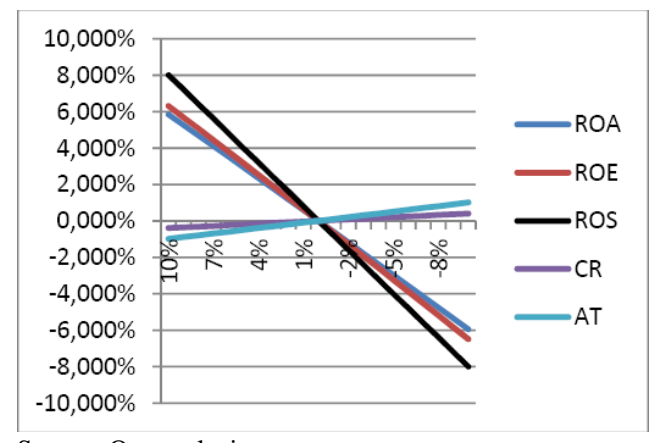

Source: Our analysis

Fig. 5. Fair value model and financial ratios I.

In line with revaluation when applying fair value model behaves all profitability ratios. Fair value model has marginal 
impact also on liquidity ratios and assets turnover, but these ratios show us inverse trend.

Following Fig. 6 provides us information about the effect of using fair value model on debt ratios and earnings per share:

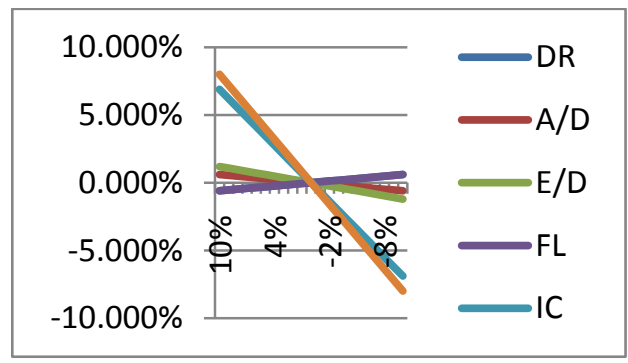

Source: Our analysis

Fig. 6. Fair value model and financial ratios II.

The most sensitive ratios when applying fair value model are EPS and interest coverage. Marginal influence of the revaluation is visible for Assets/Debts ratio and Equity/Debts ratio.

Debt ratio and financial leverage behaves similarly and show the inverse trend against other financial measures. This inverse trend could be explained by the fact that higher the value of these ratios, higher the debt exposure of the company.

\section{Revaluation Model}

Last model being a subject of our analysis is revaluation model which is currently used for realizable financial instruments. When applying this model we also have to revaluate assets at fair value, however the revaluation does not have any impact on company's profit or loss, but onto other comprehensive income (being a part of equity).

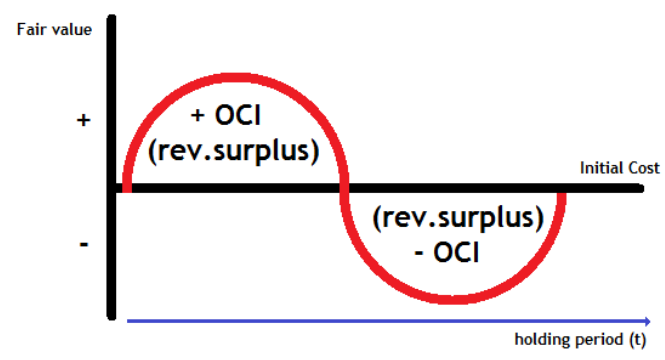

Fig. 7. Revaluation model.

Following Fig. 8 provides us information about the effect of using revaluation model on profitability ratios, liquidity ratios and assets turnover ratio:

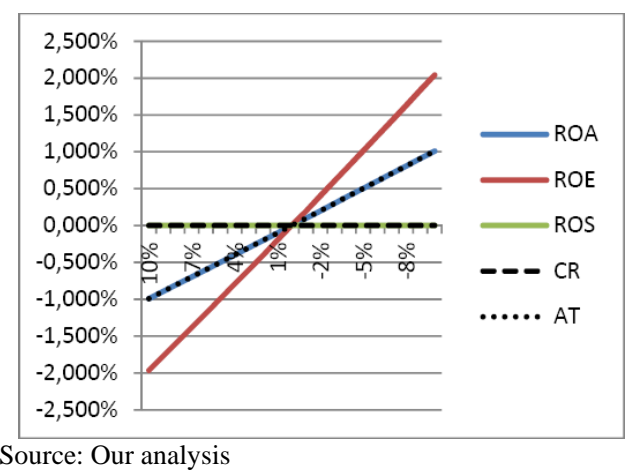

Fig. 8. Revaluation model and financial ratios I.
Applying revaluation model has any impact on ROS and current ratio. In inverse trend behaves ROE as well as other ratios (with less significant trend).

Following Fig. 9 provides us information about the effect of using revaluation model on debt ratios and earnings per share:

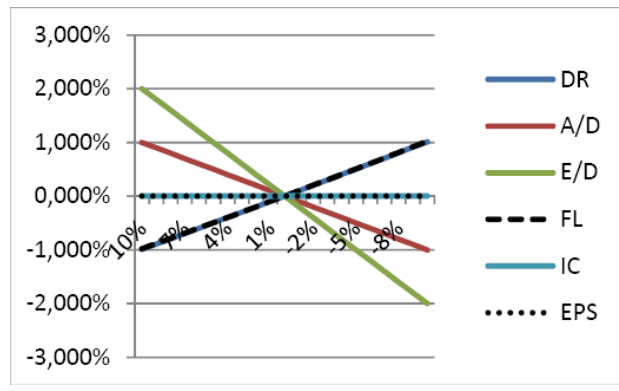

Source: Our analysis

Fig. 9. Revaluation model and financial ratios II.

Applying revaluation model has any impact on ratios EPS and interest coverage. The linear trend is visible for debt ratio and Equity/Debts ratios, however inverse trend is visible for debt ratio and financial leverage. The inverse trend could be explained by the fact that higher the value of these ratios, higher the debt exposure of the company.

Synthesis of our results is provided within following Table II:

\begin{tabular}{|l|c|c|c|}
\hline \multicolumn{2}{|c|}{ TABLE II: SYNTHESIS OF OUR RESULTS } \\
\cline { 2 - 4 } & \multicolumn{3}{|c|}{ Model } \\
\cline { 2 - 4 } & $\begin{array}{c}\text { historical } \\
\text { costs }\end{array}$ & $\begin{array}{c}\text { fair } \\
\text { value }\end{array}$ & revaluation \\
\hline ROA & + & + & - \\
\hline ROE & + & + & - \\
\hline ROS & + & + & 0 \\
\hline Current ratio & 0 & - & 0 \\
\hline Assets turnover & - & - & - \\
\hline Debt ratio & - & - & - \\
\hline Assets/Debts & + & + & + \\
\hline Equity/Debts & + & + & + \\
\hline Financial leverage & - & - & - \\
\hline Interest coverage & + & + & 0 \\
\hline EPS & + & + & 0 \\
\hline
\end{tabular}

Source: own computations

\section{CONCLUSION}

Despite there is more and more visible the trend for wider spread of fair value accounting round-out-the world because of the increasing impact of harmonized accounting legislature (IFRS, US GAAP), there could be stated that historical cost model is very popular within continental European accounting systems. This trend could be explained as a positive one, as one of the major premises for applying fair value or revaluation model is transparent active market. This cannot be stated about emerging economies (e.g. in Central and Eastern Europe).

Analysis of the impact of various models use for revaluation of assets on selected financial ratios shows us that these ratios are not very sensitive on revaluation model application, but on contrary, they are very sensitive on fair value model application. 


\section{REFERENCES}

[1] S. Aisbitt, "Measurement of harmony of financial reporting within and between countries: the case of the Nordic Countries," European Accounting Review, vol. 10, no. 1, pp. 51-72, 2002.

[2] C. N. Albu, N. Albu, and S. Fekete et al., "Implementation of IFRS for SMEs in emerging economies: stakeholder perceptions in the Czech Republic, Hungary, Romania and Turkey," Journal of International Financial Management and Accounting, vol. 24, no. 2, pp. 140-175, 2013.

[3] K. Schipper, "The introduction of international accounting standards in Europe: implication for international convergence," European Accounting Review, vol. 14, no. 1, pp. 101-126, 2005.

[4] J. Strouhal, "Comparison between reporting of listed and Nonlisted Companies in the Czech Republic," in Proc. the International Scientific Conference "Rural Development 2007", Lithuanian University of Agriculture, pp. 233-239, 2007.

[5] J. Strouhal, "Testing the compatibility between national and international accounting: Case of Czech Republic," in Proce. the 8th International Conference on E-Activities, WSEAS Press, pp. 252-256, 2009.

[6] J. Strouhal, S. Manoiu, and C. Bonaci et al., "Current developments in financial reporting convergence from SMEs perspective," La Pensee Journal, vol. 75, no. 9, 2013, forthcoming.

[7] R. C. Baker and E. M. Barber, "Trends in research on international accounting harmonization," The International Journal of Accounting, no. 42, pp. 285-286, 2007.

[8] D. L. Street and K. A. Shaughnessy, "The quest for international accounting harmonization: a review of the standard setting agendas of the IASC, US, UK, Canada and Australia 1973-1997," The International Journal of Accounting, vol. 33, no. 2, pp. 179-209, 1998.

[9] J. Strouhal, "Applicability of IFRS in the practice of Czech SMEs: Insight of Czech accounting profession representatives," in Proc. the 9th International Conference on European Financial Systems, Masaryk University Brno, 2012, pp. 214-219.

[10] J. Strouhal, "Current Measurement trends in financial reporting: from historical costs towards fair value concept (and back)?" in Proc.
International Conference on Communication and Management in Technological Innovation and Academic Globalization, WSEAS Press, 2010, pp. 27.

[11] G. Dean, "Background and case for exit price accounting," Abacus, no. 46, pp. 84-96, 2010.

[12] G. Whittington, "Measurement in financial reporting," Abacus, no. 46 pp. 104-110, 2010.

[13] R. Macve, "The case for deprival value," Abacus, no. 46, pp. 111-119 2010.

[14] IASB, Discussion Paper: Fair Value Measurement Part 1 - Invitation to Comment and Relevant IFRS Guidance, London: IASB, 2006.

[15] M. E. Barth, "Comments on panelists," Abacus, no. 46, pp. 120-127, 2010.

[16] K. Chalmers, C. Clinch, and J. M. Godfrey, "Adoption of international financial reporting standards: impact on the value relevance of intangible assets," Australian Accounting Review, vol. 18, no. 46, pp. 237-247, 2008.

[17] A. Tarca, "International convergence of accounting practices: choosing between IAS and US GAAP," Journal of International Financial Management and Accounting, vol. 15, no. 1, pp. 60-91, 2004.

[18] C. G. Bonaci and J. Strouhal, "Corporate governance lessons and traders' dilemma enhanced by the financial crisis," in Proc. the 5th WSEAS International Conference on Business Administration, WSEAS Press, 2011, pp. 66-69.

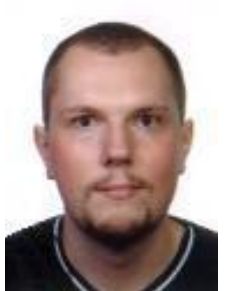

Jiří Strouhal is with the Department of Financial and Management Accounting of Škoda Auto University Mladá Boleslav. He also works in practice as a consultant of financial reporting and valuation of financial securities. Since 2011 he is a president of Chamber of Certified Accountants Czech Republic. As a researcher he did published more than 30 monographers, around 35 SCOPUS papers, 23 ISI (CPCI, SCI, BCI) papers and chapters. 